\title{
Development of Irrigation System in Paddy Cultivation Industry During British Colonialin Perak
}

\section{${ }^{1}$ Khairi Ariffin, ${ }^{2}$ Mohd Hairy Ibrahim, ${ }^{3}$ Ramli Saadon, ${ }^{4}$ Sahul Hamid Mohamed Maidin, ${ }^{5}$ Ishak Saat, ${ }^{6}$ Fauziah Che Leh, ${ }^{7}$ Mohd Kamal Kamaruddin, ${ }^{8}$ Tuan Waheda Tuan Chik}

Correspondence Author: Khairi Ariffin,

E-mail: khairi.ariffin@fsk.upsi.edu.my

Received date: 11 April 2018, Accepted date: 25 July 2018, Online date: 8 August 2018

Copyright: (c) 2018 Khairi Ariffin et al. This is an open-access article distributed under the terms of the Creative Commons Attribution License, which permits unrestricted use, distribution, and reproduction in any medium, provided the original author and source are credited.

\begin{abstract}
Before the Colonial era, agriculture was carried out to fulfill the need of peasant in small communities. Back then, peasant faced many sorts of problems to ensure the sufficiency of yields. British colonialism in Perak in 1874 had built the irrigation system which able to increase the quantity and quality of rice yield through the scheme introduced. The study was conducted using qualitative methods of analyzing the official document, annual record, proceeding and writing on British colonialism in Perak. The finding shows that Krian is one of the areas that has been the focus on irrigation system known as Krian Irrigation System. A large allocation has been spent to complete the construction of the system that is capable to increase the rice yield. Deforestation also undertaken for the construction of Sungai Manik Irrigation System, which eventually developed into a settlement. British administration left the impact on the history of the development of Perak Irrigation System and state development. The development of irrigation system implemented by the British Colonial has made Perak as an important producer of rice crop in Malay state.
\end{abstract}

Key words: Agriculture, Irrigation, Colonial, System, Paddy

\section{INTRODUCTION}

The state of Perak lies in the West of the Peninsula of Malaysia with a $100^{\circ} 30^{\prime}$ T longitude with $101^{\circ} 45$ 'and is within the $3^{\circ} 40^{\prime} \mathrm{U}$ latitude and $5^{\circ} 50^{\prime} \mathrm{U}$. [1] The state of Perak was the first state officially accept British residences after signing the Pangkor Treaty in 1874.[2]The British colonial administration had left a huge impact on changes and development in many aspects including the development of irrigation systems.

The introduction of a modern and structured irrigation system in the state of Perak is an impact from the British colonial era[3]. Before the beginning of the British's administration era, paddy cultivation in the state of Perak was carried out with traditional techniques that had been introduced through generations of generations. Even before the introduction of irrigation system, the main focus of paddy cultivation is on low alluvial soils around the valley and river valley [4].The irrigation system introduced contributed to the development of paddy crops during the British colonial period in Perak.

\section{Problem Statement:}

The British administration in the state of Perak strengthened with the implementation of the Pangkor Treaty. The British had directly involved in administrative affairs and development in Perak. British entrance has had many effects in many aspects[5].One of the impacts of the British colonial administration's intervention was in contributing to the development and change of irrigation systems in paddy cultivation.The British colonial administration in Perak also introduced innovation and change to the peasant in the state of Perak towards modern technology of agriculture and the development of rice cultivation.

\section{Research Methodology:}

This study is conducted entirely by using qualitative methods that emphasize through document analysis and manuscripts. Official documents of the British colonial government in the state of Perak such as the Perak Government Gazette, Drainage and Irrigation Department Annual Report and the Proceeding Federal Malay States files obtained from the National Archives of Malaysia have been used. The use of secondary sources such as books and study writings on agriculture and irrigation of the British colonial era in Perak and Malaya was used to strengthen the writing and information related to the study. Studies also had been conducted at public university libraries. The writing and research carried out are obtained from the university and public libraries.

\section{Result:}

At the end of the 19th century, the British colonial had initiated efforts for advocating Malay as a peasant in Perak.[6]A few districts was recorded as the best cultivation sites in Perak which comprised of Krian, Kinta and Batang Padang [7].In Krian, the British Colonial had opened and developed 6148 acres of land for paddy cultivation purpose during the end of 1890's. [8]The areas of land opened for agricultural purpose demonstrated that colonial administration had given the priority toward the agricultural sector to generate income among the peasants and increased the economy of Perak. The success of British colonial had brought Perak toward the development in terms of quality and quantity of the paddy yields. The construction of irrigation system and drainage were the main sector of paddy cultivation in Perak [9].

Before the irrigation system technology was introduced, the yields of paddy among peasants in Perak were about the same and they fully relied on the uncertain rain distribution.[10].The peasants merely depended on the rain water to fulfill the paddy cultivation demands as the local peasants had no water resource that was capable to provide water to paddy cultivation areas in a systematic way at the same time, able to control the irrigation in that particular areas. A British officer admitted that the fertility of the soil and the importance of paddy cultivation in his statement to Raja Muda Perak: 
Sir, the soil of the country is rich everywhere in the peninsula. The Malay could just go about from one place to another planting their hill paddy and drawing from the rivers their supply of fish...But, times have changed, Sir...[11].

The dependence on the rain water purely unable to fulfill the paddy cultivation demands as the rain distribution was unpredictable and beyond human control. In order to ensure the huge sum of paddy yields, a system that capable to control the depth of water with continuous water flow was really necessary.

Malay used to be associated with laziness and superstitious beliefs related to paddy cultivation [12]. Despite of being skillful in paddy cultivation, the yield of paddy in Perak was still at the unsatisfactory level. The British Colonial was aware that these characters had become an obstacle in an attempt to increase the paddy yield and required longer period to wait for the harvest. Every year, the harvest was done only once without using any sophisticated devices. Paddy is a wet plant that strictly required irrigation system which was only specific for its cultivation purpose [13].

The British Colonial administration emphasized the development aspect of agriculture in Perak. British Colonial took the step to make improvements on the technology used in paddy cultivation in Perak [14]. Hence, the colonial administration had constructed plans to develop irrigation plans in districts of Perak that potentially become paddy cultivation sites. The British Colonial had organized the Agriculture Department as the responsible body specifically to observe the quality and quantity of paddy yields and also agriculture development, literally in Perak.

The Agriculture Department was responsible in few scopes including the care of the plants that covered soil care, raise in quality and quantity of the yield, and protection of the plants against damage [15]. The agricultural activities throughout the British Colonial era was under the responsibility of the Agriculture Department. During the first twenty-five years of British administration, a sum of $\$ 122,172$ was provided specifically for the construction of the irrigation system at the paddy cultivation site at Krian under the Krian Irrigation Scheme. [16]Krian was chosen as the district had suitable sites for paddy cultivation. The yields in Krian were recorded as the highest between 1910's until 1930's. This portrayed that Krian had the condusive condition for production and cultivation of paddy.[17]

In 1937, the maintenance of the irrigation system in Krian was carried out with the cost about $\$ 60,817.20$. The maintenance involved 45.8 miles of canal, 261 miles of drainage channel, 283 watergates and regulators as well as 103 waterways and 68.3 miles of bunds.[18]The cost of improvements kept rising in exchange to ensure the Krian Irrigation System was well-kept and the maintenance was performed from time to time.

Construction of irrigation system according to Krian Irrigation Scheme also utilized animal. Four elephants were used to help the process throughout the construction in 1930 [19]. The animal was used in view of difficulty to transport heavy instruments at a path that hardly crossed by machinery or modern devices. The importance of Krian Irrigation Scheme includes improvement in water supply for irrigation by making a diversion from Sungai Ijok to the reservoir in Bukit Merah and also another new region at Hutan Simpan Kuala Kurau with the estimated area of 3000 acres [20].

Apart from Krian, Kuala Kangsar was also an important rice paddy producer with an area of 8876 acres in 1947.[21]The irrigation and drainage system were executed easier because the Irrigation and Drainage Department Office had been moved from Ipoh to Kuala Kangsar on 1 st June 1939 when it was managed by A.I.G.S Robertson's engineers.[22]In 1947, the British administrative had funded about $\$ 5,400$ and introduced incentives in the form of cash and aids to the peasants using the provided funds.[23]

Hilir Perak areas were another important paddy cultivation site with the areas of 23000 acres in 1935. Sungai Manik that was located 3 miles from the north of Teluk Anson was chosen as the site for irrigation and drainage system construction through the main scheme plan in 1932 as Sungai Manik was the only area that least covered by the forest.[24]Deforestation of 150 acres of land to build a canal was the initiation plan for the construction of irrigation system. [25]The cost that was spent during the initial phase of construction until the end of the year was $\$ 60,409.17$ and for the maintenance, the cost was estimated around $\$$ 815,658.[26]The State Irrigation Body had implemented the guidelines to separate blocks at the paddy cultivation sites. The separation was influenced by two methods which were pre-survey and post survey. In every 6 acres of land, 1/4 acre was marked as special for hut and as the site for drying process. The second method was the survey of the determined selected sites while 50 acres of block were reserved for a family or a group of races. These areas that were separated according to the blocks were called as village and determined by Land Office and Drainage and Irrigation Department [27]. The officer of Irrigation and Drainage Department had agreed that every block that was divided deserved to be addressed as a village.

\section{Conclusion:}

Agriculture specifically paddy cultivation before the colonial era was merely for subsistence and only done to fulfill their life necessities. The introduction to irrigation plans in Perak and the implementation on of technology in irrigation system led to positive transformation toward the paddy yields. Construction of sophisticated drainage system in the context of technology aspect had troubleshoot the obstacles faced by the traditional peasants before the colonial era. In the long term, the introduction of a systematic irrigation system had become a pioneer in the development of technology and irrigation system management specifically for the benefit of paddy cultivation.

\section{ACKNOWLEDGEMENT}

This'll article was a result of research grant FRGS funded by Ministry of Higher Education under the supervision of Research, Management and Innovation Centre (RMIC) Universiti Pendidikan Sultan Idris. Research code: FRGS: 2017-0083-02.

\section{REFERENCES}

[1] Zabidin Ismail, 2013. Menara Condong Teluk Intan. Kuala Lumpur:Institut Terjemahan Buku Malaysia. P.1

[2] The Pangkor agreement was signed between the British and the Sultan of Perak after Sir Andrew Clarke convinced him to accept a responsibility as a Resident in administration without involving interference in religious affairs and customs. See Federal Malay State Government Gazette. Pg 2.

[3] Short, D.E. and J.C. Jackson, 1971. The Origin of An Irrigation Policy in Malaya: A Review of Development Prior to Establishment of the Drainage and Irrigation Department. JMBRAS, 44(1).

[4] James, C., Jackson, 1972. Rice Cultivation in West Malaysia, JMBRAS, 45(2).

[5] Nordin Husin, 1990. Larut Matang dan Selama Suatu Sorotan Sejarah, Seminar Sejarah Larut, Matang dan Selama Ke Arah Taiping Bandar Bersejarah, Jabatan Muzium Negara, p.1

[6] Badriyah Salleh, 1988. Proses Mempetanikan Orang Melayu di daerah Batang Padang Akhir Kurun ke-19 in Perak Dahulu dan Sekarang, 77.

[7] Annual Report on the State of Perak, 1896. p.8

[8] Ibid.

[9] Short, D.E., J.C. Jackson, 1971. The Origin of An Irrigation Policy in Malaya: A Review of Development Prior to Establishment of the Drainage and Irrigation Department. JMBRAS, 44(1):79.

[10] Federated Malay State Agriculture Department, Bulletin no 1-17, 1909-1916. p.8

[11] Federated Malay Stated Shorthand Report of the Proceeding of the Federal Council, 1933.

[12] Bulletin No 12, Padi Cultivation in Krian, 1911. Department of Agriculture Federated Malay State, 3.

[13] Annual Report on the State of Perak, 1896. p.8

[14] Mc Nair, J.F., 1972, Perak and The Malays, Kuala Lumpur: Oxford University Press, 71.

[15] Perak Administration Report, 1925. p.6

[16] Annual Report on the state of Perak, 1896.

[17] Annual Report on Sosial and Economic People of Perak, 1934.

[18] Annual Report Drainage and Irrigation Department, 1936.

[19] Perak Administration Report 1930. pp: 20.

[20] Federated Malay States, 1935. Report on The Progress Of Schemes For The Improvement and Extension of Rice Cultivation.

[21] Perak Secretariat 637/1948. District and Land Office Kuala Kangsar 1947

[22] Perak Annual Report, 1939. 
[23] Perak Secretariat, 637/1948. District and Land Office Kuala Kangsar 1947

[24] Federated malay States, 1935. Report on The Progress Of Schemes For The Improvement and Extension of Rice Cultivation.

[25] Annual Report Drainage and Irrigation Department Federated Malay States, 1932.

[26] Ibid.

[27] Ibid. 